\title{
Platelet Kinetics in Idiopathic Thrombocytopenic Purpura Patients Treated with Thrombopoietin Receptor Agonists
}

\author{
Oliver Meyer $^{a} \quad$ Eric Herzig ${ }^{b} \quad$ Abdulgabar Salama $^{a}$ \\ a Institut für Transfusionsmedizin, Abteilung Innere Medizin und Poliklinik, Charité - Universitätsmedizin Berlin, \\ ${ }^{\mathrm{b}}$ Ambulantes Gesundheitszentrum der Charité GmbH, Nuklearmedizin mit PET/CT, Berlin, Germany
}

\section{Keywords}

Platelet survival · Platelet kinetics .

Thrombopoietin · Romiplostim · Eltrombopag

\section{Summary}

Aim: Thrombopoietin receptor agonists (Tpo RA) increase platelet counts in the majority of chronic autoimmune thrombocytopenia (idiopathic thrombocytopenic purpura; ITP) patients. It is unknown whether this treatment may also improve platelet survival (PS) in these patients. Methods: In order to determine platelet survival (PS), autologous platelets were labeled with ${ }^{111}$ In oxine and retransfused in six patients under treatment with Tpo RA (romiplostim $n=3$; eltrombopag $n=3$ ). Results: Stable platelet counts of greater than $100 \times 10^{3} / \mu$ were observed in all 6 patients. Platelet survival was decreased in all cases (mean 2.10 days; range $0.13-3.73$ days). No correlation was found between platelet count and PS. Similarly, there was no significant relationship between platelet turnover and platelet count. However, a high platelet turnover, exceeding 25 or three times the norm was observed in 2 patients who presented the lowest PS (0.13 or 0.83 days). Two patients had a moderately shortened PS (1.91 or 2.42 days), and, correspondingly, a moderately increased platelet turnover rate $(63,072$ or 72,872 platelets/ul/day). Conclusion: These results indicate that Tpo RA may not only overcompensate platelet destruction in ITP, but may interfere with other mechanisms, which, in some cases, results in a reduced platelet destruction rate.

\section{Schlüsselwörter \\ Thrombozytenüberleben - Thrombozytenkinetik . Thrombopoetin · Romiplostim · Eltrombopag}

\section{Zusammenfassung}

Hintergrund: Die Behandlung mit Thrombopoetin-Rezeptor-Agonisten (Tpo RA) führt bei den meisten Patienten mit Autoimmunthrombozytopenie zu einem Anstieg der Thrombozytenzahl. Derzeit ist allerdings unklar, ob diese Behandlung auch zu einer Verbesserung der Thrombozytenüberlebenszeit bei diesen Patienten führt. Methoden: Um die Thrombozytenüberlebenszeit zu bestimmen, wurden autologe Thrombozyten mit ${ }^{111}$ In-Oxin markiert und 6 Patienten retransfundiert, die bereits längere Zeit mit Tpo RA behandelt waren. Ergebnisse: Alle Patienten hatten zum Zeitpunkt der Untersuchung stabile Thrombozytenzahlen $\left(>100 \times 10^{3} / \mu \mathrm{l}\right)$. Bei allen Patienten fand sich eine verminderte Thrombozytenüberlebenszeit (Median 2,10 Tage; Bereich 0,13-3,73 Tage). Es war keine Korrelation zwischen Thrombozytenzahl und Thrombozytenüberlebenszeit erkennbar. Darüber hinaus war auch kein Zusammenhang zwischen Thrombozytenzahl und Thrombozytenumsatz erkennbar. Allerdings fiel bei $2 \mathrm{~Pa}-$ tienten ein deutlich erhöhter Thrombozytenumsatz (um das bis zu 25-fache der Norm) auf. Bei diesen beiden Patienten wurden auch die kürzesten Überlebenszeiten gemessen (0,13 bzw. 0,83 Tage). Bei 2 weiteren Patienten wurde eine mäßige verkürzte Thrombozytenüberlebenszeit gemessen (1,91 bzw. 2,42 Tage). Bei diesen Patienten war auch der Thrombozytenumsatz mäßig gesteigert (63 072 bzw. 72872 Thrombozyten/ul/Tag). Schlussfolgerung: Die vorgestellten Ergebnisse zeigen, dass die Behandlung der ITP mit Tpo RA nicht nur zu einer Überkompensation des Thrombozytenabbaus führt, sondern in einigen Fällen auch über andere Mechanismen zu einem verminderten Thrombozytenabbau führen kann.

\section{KARGER \\ Fax +497614520714 \\ Information@Karger.de}

www.karger.com
(C) 2012 S. Karger GmbH, Freiburg

$1660-3796 / 12 / 0391-0005 \$ 38.00 / 0$

Accessible online at:

www.karger.com/tmh
Prof. Dr. Abdulgabar Salama

Institut für Transfusionsmedizin

Charité - Universitätsmedizin Berlin

Augustenburger Platz 1, 13353 Berlin, Germany

Tel. +49 30450 553-012, Fax -932

abdulgabarsalama@charite.de 


\section{Introduction}

Chronic autoimmune thrombocytopenia (idiopathic thrombocytopenic purpura; ITP) is characterized by a reduced platelet count, antibody-mediated platelet destruction, and a significant decrease in platelet survival (PS). Impaired platelet production and T-cell-mediated platelet destruction has been implicated as playing a potential role [1]. Approximately $40 \%$ of patients with ITP display a reduced platelet turnover [2], and megakaryocytes are often decreased and/or damaged [3-5]. It has also been demonstrated that ITP patients have normal or only slightly increased levels of thrombopoietin (Tpo) $[6,7]$. Furthermore, studies with thrombopoietin receptor agonists (Tpo RA) have demonstrated a dose-dependent response with a significant increase in platelets in almost $80 \%$ of patients treated for ITP. This platelet increase is not predictable or dose-dependent and varies amongst patients $[8,9]$. A recent study demonstrated that Tpo RA resulted in the improvement of regulatory T-cell activity in ITP patients [10]. All these findings indicate that the effect of Tpo RA in ITP might not solely be explained by an increased platelet production that overcompensates platelet destruction. To further elucidate this, platelet kinetics were measured in 6 ITP patients treated with Tpo RA.

\section{Patients and Methods}

We evaluated the treatment course of 6 patients (age range, 55-82 years) with chronic ITP (splenectomized $n=3$; non-splenectomized $n=3$ ). Diagnosis of ITP was made according to established guidelines [11, 12]. All patients were individually treated with Tpo RA (3 received Revolade ${ }^{\circledR}$, GlaxoSmithKline GmbH, Munich, Germany; 3 received Nplate ${ }^{\circledR}$; Amgen $\mathrm{GmbH}$, Munich, Germany) for more than 6 months (6-36 months). Prior to treatment with Tpo RA, all 6 patients demonstrated severe ITP, and platelet counts were below $20 \times 10^{9} / \mu 1$.

Written informed consent was obtained from all participating patients. All patients had stable platelet counts of $>100 \times 10^{9} / \mu$ l during the investigation (table 1). Autologous platelets were labeled with ${ }^{111}$ In oxine using a standard technique [13]. Following platelet retransfusion, venous blood samples were collected at 5, 10, 30, 45, 60, and $90 \mathrm{~min}$, at 3-4 h, and on a daily basis post transfusion until the level of radioactivity was reduced to $10 \%$ of the maximum activity. Depending on the slope of the curve, supplemental samples were taken. In addition, radioactivity counts of the heart, liver, spleen, and bone marrow were obtained using the ROI technique. PS was calculated by the gamma function, whereas platelet turnover was determined using the following formula:

Platelet count $($ platelets $/ \mu \mathrm{l} /$ day $)=\frac{\text { platelet count }(/ \mu \mathrm{l}) \times \text { platelet recovery }(\%)}{\text { platelet survival }(\text { days })}(1)$

and corrected (90\%) for recovery in non-splenectomized patients [14, 15].

\section{Results}

Although platelet counts were observed to be greater than $100 \times 10^{9} / \mu 1$, PS was reduced in all patients, ranging between 0.13 and 3.73 days (table 2). In correspondence to the latter finding, platelet turnover increased to more than 25 times the normal rate in 1 patient presenting the lowest PS (no. 1), and to a lesser degree in 3 other patients (no. 4, 5, and 6). No significant correlation between PS and platelet count or PS and platelet turnover was observed (fig. 1,2). Based on normal values from previous studies (see discussion), PS may have

Table 1. Characteristics of treated patients

\begin{tabular}{|c|c|c|c|c|c|c|c|c|}
\hline Patient no. & $\begin{array}{l}\text { Age, } \\
\text { years }\end{array}$ & Sex & $\begin{array}{l}\text { Disease, } \\
\text { years }\end{array}$ & Previous treatment & $\begin{array}{l}\text { Eltrombopag, } \\
\mathrm{mg} / \text { day }\end{array}$ & $\begin{array}{l}\text { Romiplostim, } \\
\mu \mathrm{g} / \mathrm{kg} / \text { week }\end{array}$ & $\begin{array}{l}\text { Platelets prior to } \\
\text { Tpo-R-Mimetics } \\
\times 10^{9} / 1\end{array}$ & $\begin{array}{l}\text { Duration of } \\
\text { treatment with Tpo- } \\
\text { R-Mimetics, days }\end{array}$ \\
\hline 1 & 73 & M & $>5$ & PRED, IVIg, anti-D & 75 & & 19 & 152 \\
\hline 2 & 80 & $\mathrm{~F}$ & 12 & PRED, IVIg & 50 & & 16 & 138 \\
\hline 3 & 57 & $\mathrm{~F}$ & 2 & PRED, IVIg, CsA, Splx & 25 twice weekly & & 14 & 125 \\
\hline 4 & 70 & M & 5 & PRED, MYCO, Splx & & 1 & 9 & 26 \\
\hline 5 & 81 & $\mathrm{~F}$ & 5 & PRED, IVIg, AZA, Splx & & 3 & 6 & 43 \\
\hline $6^{*}$ & 55 & $\mathrm{f}$ & $>20$ & PRED, AZA & & 3 & 13 & 30 \\
\hline
\end{tabular}

Table 2. Results of ${ }^{111}$ In platelet kinetics

\begin{tabular}{lllllr}
\hline Patient no. & $\begin{array}{l}\text { Platelets at measurement } \\
\times 10^{9} / 1\end{array}$ & $\begin{array}{l}\text { platelet half-life } \\
\text { time, } \mathrm{h}\end{array}$ & Recovery, \% & $\begin{array}{c}\text { Survival, days } \\
\text { Turnover, } \\
\text { platelets/ } \mu \mathrm{l} / \text { day }\end{array}$ \\
\hline 1 & 158 & 3.1 & 94.40 & 0.13 & $1,107,398$ \\
2 & 131 & 89.5 & 90.75 & 3.73 & 34,830 \\
3 & 226 & 60.9 & 94.50 & 3.60 & 57,025 \\
4 & 138 & 40.9 & 93.80 & 1.91 & 63,072 \\
5 & 125 & 47.7 & 83.50 & 0.83 & 180,362 \\
6 & 176 & 58.0 & 81.60 & 2.42 & 72,872 \\
\hline
\end{tabular}


Fig. 1. Correlation between PS and platelet turnover. No significant correlation was observed $(r=-0,739, p=0.094)$.
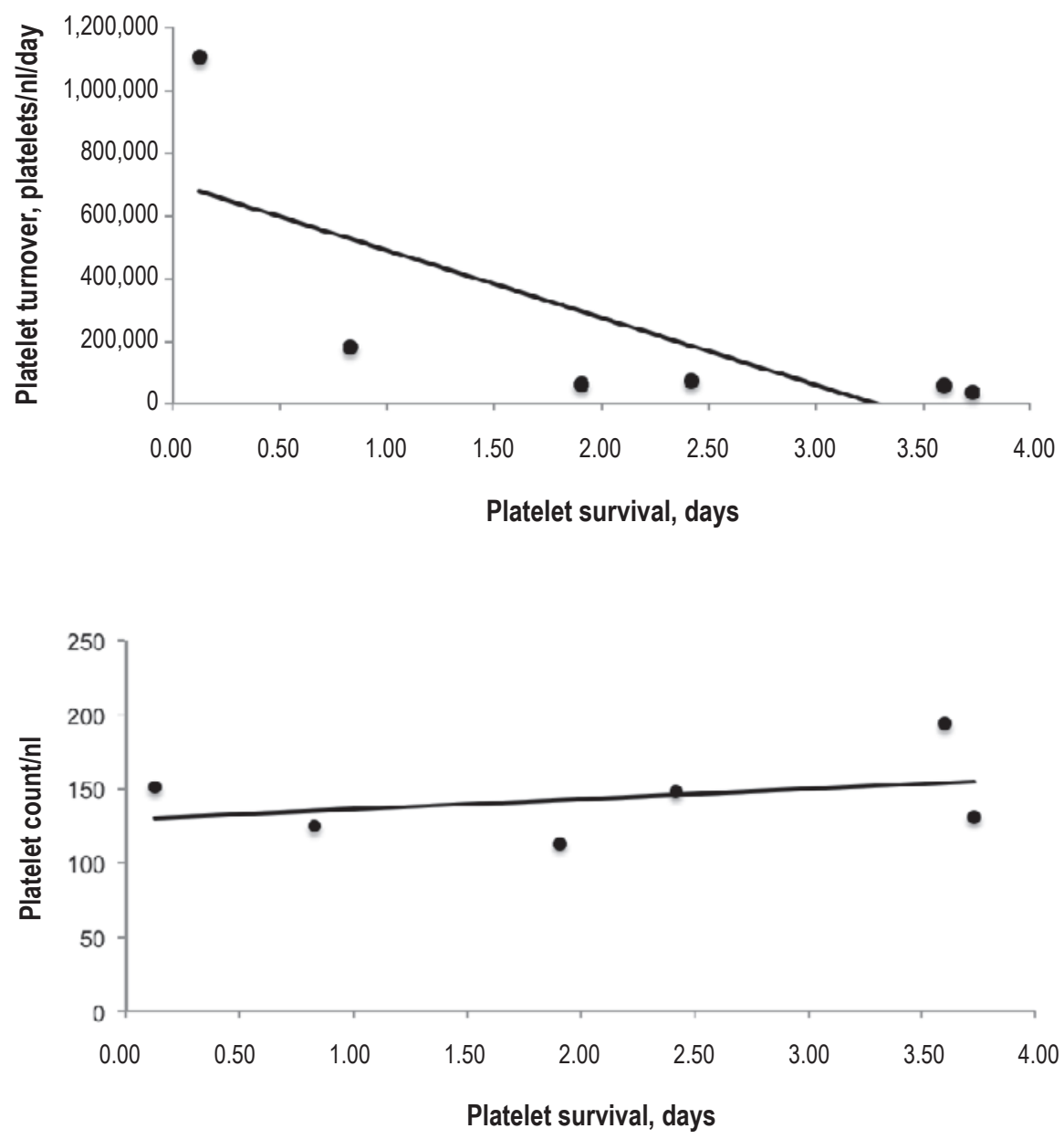

Platelet survival, days
Fig. 2. Correlation between PS and platelet count. No significant correlation was observed $(\mathrm{r}=0.3450, \mathrm{p}=0.503)$. moderately been increased or did not significantly change in the remaining 2 patients (no. 2 and 3). During observation of more than 2 years, continuous treatment with Tpo RA ensured 'safe' platelet counts in these patients.

\section{Discussion}

Previous studies have revealed a normal PS to be 7-10 days, whereby platelet turnover rates ranged between 40,000 to 60,000 platelets/nl/day. In ITP, a significantly decreased PS of several days or even hours has been observed. There was no clear correlation between platelet count and PS. Of extreme interest was the finding that increased platelet production was observed in approximately one third of ITP patients, whereas one third presented a decrease in platelet production $[16,17]$.

Though numerous therapies are useful in the treatment of ITP, only several studies have addressed platelet kinetics in treated patients. These studies revealed varying results, which included no change, increase, decrease, or normalization of platelet turnover following treatment with corticosteroids and splenectomy [18-24]. This is not surprising as several other factors are involved in the pathogenesis of ITP and may influ- ence therapeutic effects. These include the concentration of endogenous Tpo, concentration and affinity of platelet autoantibodies, capability of macrophages to recognize and eliminate platelets from the circulation, and platelet production. Since any change of one or more factors may influence all findings in ITP, it is not surprising that the results obtained from different studies are different. This is supported by our findings in the present study. Prior to treatment with Tpo RA, all 6 patients presented with severe ITP, with platelet counts below $20 \times 10^{9} / \mu 1$. Platelet counts increased to greater than $100 \times 10^{9 /} \mu \mathrm{l}$ in all patients post treatment. However, platelet counts were not found to correlate with PS, and platelet turnover remained variable among the patients. Although patients who demonstrated the highest reduction in PS also exhibited the highest platelet turnover, no significant correlation was found with platelet counts or PS. Due to the fact that PS is known to be decreased in ITP patients, we were unable to justify the measurement of PS prior to treatment with Tpo RA. Thus, it remains unknown as to how these drugs alter platelet kinetics in ITP patients. However, there is evidence that the stable rise in platelet counts cannot be solely explained by an increase in platelet production which exceeds platelet destruction, at least in patients that demonstrated a 
relatively normal platelet turnover. There are two possible explanations for this phenomenon. Macrophages have a diminished capability of destroying platelets in these patients when compared to patients with a higher turnover, resulting in their reduction due to the elimination of additional platelets, leading to increased PS. A similar phenomenon occurs in ITP patients following transfusion of high doses of platelets [25] and coating of autologous red blood cells with antibodies, i.e. anti-D [26]. Another factor leading to the normalization in platelet turnover is the direct effect of Tpo RA on regulatory T-cell activity. Further studies on larger cohorts and pre- and post-treatment analysis are required to further elucidate these mechanisms.

\section{Acknowledgement}

We thank Dr. Sundrela Kamhieh-Milz for editing and drafting the manuscript.

O.M. treated the patients, planned the study, analyzed the data and wrote the manuscript; E.H. performed the platelet kinetics and analyzed the data; A.S. planned the study, analyzed the data, and wrote the manuscript.

\section{Disclosure Statement}

A.S. and O.M. conduct clinical studies on behalf of Amgen and GlaxoSmithKline and received consultation fees from Amgen and GlaxoSmithKline. E.H. declares no conflict of interest.

\section{References}

1 Cines DB, Bussel JB, Liebman HA, Luning Prak ET: The ITP syndrome: pathogenic and clinical diversity. Blood 2009;113:6511-6521.

$\checkmark 2$ Louwes H, Zeinali Lathori OA, Vellenga E, de Wolf JT: Platelet kinetic studies in patients with idiopathic thrombocytopenic purpura. Am J Med 1999;106:430-434.

> 3 Hoffman R, Zaknoen S, Yang HH, Bruno E, LoBuglio AF, Arrowsmith JB, et al: An antibody cytotoxic to megakaryocyte progenitor cells in a patient with immune thrombocytopenic purpura. $\mathrm{N}$ Engl J Med 1985;312:1170-1174.

4 Chang M, Nakagawa PA, Williams SA, Schwartz MR, Imfeld KL, Buzby JS, et al: Immune thrombocytopenic purpura (ITP) plasma and purified ITP monoclonal autoantibodies inhibit megakaryocytopoiesis in vitro. Blood 2003;102:887-895.

$\checkmark 5$ Houwerzijl EJ, Blom NR, van der Want JJ, Esselink MT, Koornstra JJ, Smit JW, et al: Ultrastructural study shows morphologic features of apoptosis and para-apoptosis in megakaryocytes from patients with idiopathic thrombocytopenic purpura. Blood 2004;103:500-506.

$\checkmark 6$ Nichol JL: Endogenous TPO (eTPO) levels in health and disease: possible clues for therapeutic intervention. Stem Cells 1998;16(suppl 2):165-175.

7 Kappers-Klunne MC, de Haan M, Struijk PC, van Vliet HH: Serum thrombopoietin levels in relation to disease status in patients with immune thrombocytopenic purpura. Br J Haematol 2001;115:10041006.

8 Kuter DJ: Thrombopoietin and thrombopoietin mimetics in the treatment of thrombocytopenia. Annu Rev Med 2009;60:193-206.
9 Stasi R, Bosworth J, Rhodes E, Shannon MS, Willis F, Gordon-Smith EC: Thrombopoietic agents Blood Rev 24:179-190.

10 Bao W, Bussel JB, Heck S, He W, Karpoff M, Boulad N, et alx: Improved regulatory T-cell activity in patients with chronic immune thrombocytopenia treated with thrombopoietic agents. Blood 116:4639-4645.

11 George JN, Woolf SH, Raskob GE, Wasser JS, Aledort LM, Ballem PJ, et al: Idiopathic thrombocytopenic purpura: a practice guideline developed by explicit methods for the American Society of Hematology. Blood 1996;88:3-40.

12 Force BCfSiHGHT: Guidelines for the investigation and management of idiopathic thrombocytopenic purpura in adults, children and in pregnancy. Br J Haematol 2003;120:574-596.

13 Mathias CJ, Welch MJ: Radiolabeling of platelets. Semin Nucl Med 1984;14:118-127.

14 Harker LA, Finch CA: Thrombokinetics in man. J Clin Invest 1969;48:963-974.

15 Hematology TPoDAoRi, Hematology ICoSi: Recommended methods for radioisotope platelet survival studies: by the panel on Diagnostic Application of Radioisotopes in Hematology, International Committee for Standardization in Hematology. Blood 1977;50:1137-1144.

16 Leissinger CA: Platelet kinetics in immune thrombocytopenic purpura and human immunodeficiency virus thrombocytopenia. Curr Opin Hematol 2001;8:299-305.

17 Gernsheimer T: Pathophysiology and thrombokinetics in autoimmune thrombocytopenia. Blood Rev 2002;16:7-8.
18 Najean Y, Ardaillou N, Caen J, Larrieu MJ, Bernard J: Survival of radiochromium-labeled platelets in thrombocytopenias. Blood 1963;22:718-732.

19 Aster RH, Jandl JH: Platelet sequestration in man. II. Immunological and clinical studies. J Clin Invest 1964;43:856-869.

20 Aster RH, Jandl JH: Platelet sequestration in man. I. Methods. J Clin Invest 1964:43:843-855.

21 Gehrmann G, Bleifeld W. Survival time and site of disintegration of human thrombocytes in various forms of thrombopenia (in German). Blut 1968;17: 266-275.

22 Branehog I: Platelet kinetics in idiopathic thrombocytopenic purpura (ITP) before and at different times after splenectomy. Br J Haematol 1975;29: 413-426.

23 Gernsheimer T, Stratton J, Ballem PJ, Slichter SJ: Mechanisms of response to treatment in autoimmune thrombocytopenic purpura. N Engl J Med 1989;320:974-980.

24 Stratton JR, Ballem PJ, Gernsheimer T, Cerqueira $\mathrm{M}$, Slichter SJ: Platelet destruction in autoimmune thrombocytopenic purpura: kinetics and clearance of indium-111-labeled autologous platelets. J Nucl Med 1989;30:629-637.

25 Salama A, Kiesewetter H, Kalus U, Movassaghi K, Meyer O: Massive platelet transfusion is a rapidly effective emergency treatment in patients with refractory autoimmune thrombocytopenia. Thromb Haemost 2008;100:762-765.

26 Salama A: Current treatment options for primary immune thrombocytopenia. Expert Rev Hemato 4:107-118. 